\title{
Pengaruh Pemahaman Materi Wakalah dan Sulhu terhadap Tanggung Jawab dan Cinta Damai Siswa di Madrasah Aliyah Hasanah Pekanbaru
}

\author{
Hermi Yusnita*, Nurhayati Zein** \\ * Mahasiswa Pendidikan Agama Islam, Universitas Islam Negeri Sultan Syarif Kasim Riau \\ ** Pendidikan Agama Islam, Universitas Islam Negeri Sultan Syarif Kasim Riau
}

\section{INFO ARTIKEL}

Riwayat Artikel:

Diterima: $15-12-2019$

Disetujui: 22-12-2019

\section{Kata kunci:}

Pemahaman

Wakalah dan Sulhu

Tanggung Jawab dan Cinta Damai

\author{
Alamat Korespondensi: \\ Nurhayati Zein \\ Pendidikan Agama Islam, Universitas Islam Negeri Sultan Syarif Kasim Riau \\ Jl. Manunggal, Pekanbaru-Bangkinang \\ E-mail: nurhayati.zein@uin-suska.ac.id

\begin{abstract}
ABSTRAK
Abstract: This study aims to determine the effect of understanding wakalah and sulhu material on students' responsibility and peace-loving in the environment of Madasah Aliyah Hasanah Pekanbaru. The subjects of this study were students at Madasah Aliyah Hasanah Pekanbaru. While the object in this study is the influence of understanding the material of wakalah and sulhu on the responsibilities and peace-loving students. The population in this study was class X students, amounting to 24 students. The sampling technique in this study uses a census sampling (saturated sample). Data collection techniques in this study used observation, tests, questionnaires, and documentation. While the data analysis technique uses serial correlation. Data calculation is done manually obtained through tests and questionnaires. Test to get data about understanding wakalah and sulhu material. While the questionnaire to get data about the responsibilities and peace of love of students. Based on the analysis of the data obtained rch of 0.771 is greater than rtable both at a significant level of $5 \%$ by 0.404 and a significant level of $1 \%$ by 0.515 or $0.404<0.771>$ 0.515 . Thus $\mathrm{Ha}$ is accepted and $\mathrm{HO}$ is rejected. The conclusion of this study is that there is a significant influence between understanding the material of wakalah and sulhu on the responsibility and love of peace of students during the Madasah Aliyah Hasanah Pekanbaru environment.
\end{abstract}

Abstrak: Penelitian ini bertujuan untuk mengetahui pengaruh pemahaman materi wakalah dan sulhu terhadap tanggung jawab dan cinta damai siswa selama di lingkungan Madasah Aliyah Hasanah Pekanbaru. Subjek penelitian ini adalah siswa di Madasah Aliyah Hasanah Pekanbaru. Sedangkan objek dalam penelitian ini adalah pengaruh pemahaman materi wakalah dan sulhu tehadap tanggung jawab dan cinta damai siswa. Adapun populasi dalam penelitian ini adalah siswa kelas X yang berjumlah 24 siswa. Teknik pengambilan sampel pada penelitian ini menggunakan sensus sampling (sampel jenuh). Teknik pengumplan data dalam penelitian ini menggunakan observasi, tes, angket, dan dokumentasi. Sedangkan teknik analisis datanya menggunakan korelasi serial. Perhitungan data dilakukan secara manual yang diperoleh melalui tes dan angket. Tes untuk mendapatkan data tentang pemahaman materi wakalah dan sulhu. Sedangkan angket untuk mendapatkan data tentang tanggung jawab dan cinta damai siswa. Bedasarkan analisis data diperoleh rch sebesar 0,771 lebih besar dari rtabel baik pada taraf signifikan 5\% sebesar 0,404 dan taraf signifikan $1 \%$ sebesar 0,515 atau $0,404<0,771>0,515$. Dengan demikian Ha diterima dan $\mathrm{HO}$ ditolak. Kesimpulan penelitian ini adalah ada pengaruh yang signifikan antara pemahaman materi wakalah dan sulhu terhadap tanggung jawab dan cinta damai siswa selama di lingkungan Madasah Aliyah Hasanah Pekanbaru.

\section{LATAR BELAKANG}

Manusia adalah makhluk tuhan yang bisa dididik. Tidak ada seorangpun yang bisa melepaskan diri dari hakikat kodrat ini. Oleh karena itu, manusia harus mengikuti proses pendidikan selama hidupnya. Inilah yang kemudian dikenal dengan pendidikan sepanjang hayat. Di samping itu, manusia juga sebagai makhluk sosial yang tidak bisa melepaskan diri dari lingkungannya, baik dikeluarganya maupun di tengah-tengah masyarakat. Kedua ranah ini menjadi arena bagi manusia untuk mengembangkan diri dan perilakunya, apakah nantinya ia akan memiliki karakter yang mulia atau karakter yang 
buruk (Marzuki, 2015). Di era globalisasi seperti sekarang ini, ancaman hilangnya karakrer semakin nyata. Nilai-nilai karakter yang luhur tergerus oleh arus globalisasi (Barnawi dan M. Arifin, 2016). Dengan arus teknologi informasi yang semakin berkembang, yang dapat mempengaruhi karakter yang dimiliki oleh masyarakat baik itu dari kalangan anak-anak maupun dewasa. Maka, nilai karakter memang harus ditanam kuat dalam diri individu itu sendiri. Karenanya pendidikan yang berbasis karakter itu sangat penting untuk diterapkan. Pendidikan Nasional bertujuan: "untuk mengembangkan potensi peserta didik agar menjadi manusia yang beriman dan bertakwa kepada tuhan yang maha esa, berakhlak mulia, sehat, berilmu, cakap, kreatif, mandiri, dan menjadi warga negara yang demokratis serta bertanggung jawab" (UU Sisdiknas No. 20 Tahun 2003 Pasal 3) (Anas Salahudin dan Irwanto Alkrienciehie, 2013). Salah satu upaya untuk mewujudkan pendidikan yang menghasilkan manusia berkarakter mulia, para peserta didik harus dibekali dengan pendidikan khusus yang membawa misi pokok dalam pembinaan karakter mereka. Pendidikan seperti ini dapat memberi arah kepada peserta didik setelah menerima berbagai ilmu maupun pengetahuan dalam bidang studi (mata pelajaran) masing-masing. Sehingga mereka dapat mengamalkannya di tengah-tengah masyarakat dengan tetap berpatokan pada nilai-nilai kebenaran dan kebaikan yang universal (Marzuki, 2015).

Dalam implementasi kurikulum 2013, pendidikan karakter dapat diintegrasikan dalam seluruh pembelajaran pada setiap bidang studi yang terdapat dalam kurikulum (Marzuki, 2015). Pengintegrasian materi maksudnya adalah mengintegrasikan konsep atau karakter ke dalam materi yang sedang diajarkan. Jadi, Materi pembelajaran yang berkaitan dengan norma atau nilai-nilai pada setiap bidang studi perlu dikembangkan, dihubungkan dengan konteks kehidupan sehari-hari. Jadi guru bukan hanya sekedar menjelaskan teori pembelajaran saja, akan tetapi juga menanamkan nilai-nilai dalam proses pembelajaran dengan cara memberikan teladan pada peserta didik dengan nilai-nilai karakter tersebut. Agar para siswa tidak hanya menguasai kompetensi (materi) yang ditargetkan, tapi juga dirancang dan dilakukan untuk menjadikan peserta didik mengenal, menyadari/peduli, dan menginternalisasi nilai-nilai menjadi perilaku. Untuk menghasilkan siswa yang memiliki karakter yang baik dan dapat mengamalkan ilmunya dalam kehidupan, maka siswa tidak hanya dapat menghafal materi pelajaran saja. Melainkan ia juga harus bisa memahami apa yang ia pelajari. Pemahaman atau comprehension adalah kemampuan seseorang untuk mengerti dan memahami setelah sesuatu itu diketahui dan diingat (Anas Sudijono, 2011).

Seorang peserta didik dikatakan memahami sesuatu apabila ia dapat mengembangkan konsep/meteri yang dipelajari dengan kata-katanya sendiri atau dapat menyelesaikan persoalan dengan pemikirannya sendiri. Menurut Anas Sudijono (2011), "aplikasi atau penerapan mencakup pemahaman dan pengetahuan". Jadi dapat dipahami bahwa siapa yang bagus penguasaannya terhadap materi maka siswa tersebut akan mengaplikasikannya dalam kehidupan sehari-hari. Dengan demikian, jika seseorang sudah paham akan sesuatu ilmunya maka akan mudah dalam mempraktekkannya. Pemahaman seseorang didapat dari ilmu yang dipelajarinya. Dan ilmu tersebut merupakan dasar dari segala tindakan seseorang. Jika seseorang berilmu maka ia harus diiringi dengan amal perbuatan. Sama halnya jika siswa yang telah diberikan ilmu maka perbuatannya pun akan sesuai dengan ilmu yang ia dapati.

Salah satu mata pelajaran yang harus dipahami oleh siswa adalah mata pelajaran Fikih. Mata pelajaran Fikih adalah salah satu mata pelajaran Pendidikan Agama Islam yang merupakan peningkatan dari Fikih yang telah dipelajari oleh peserta didik di Madrasah Tsanawiyah. Peningkatan tersebut dilakukan dengan cara mempelajari, memperdalam, serta memperkaya kajian Fikih baik yang menyangkut aspek ibadah maupun muamalah, yang dilandasi oleh prinsip-prinsip dan kaidah-kaidah Ushul Fikih serta menggali tujuan dan hikmahnya, sebagai persiapan untuk melanjutkan ke pendidikan yang lebih tinggi dan untuk hidup bermasyarakat. Secara substansial, mata pelajara Fikih memiliki konstribusi dalam memberikan motivasi kepada peserta didik untuk mempraktikkan dan menerapkan hukum Islam dalam kehidupan sehari-hari sebagai perwujudan keserasian, keselarasan, dan keseimbangan hubungan manusia dengan Allah swt., dengan diri manusia itu sendiri, sesama manusia, makhluk lainnya ataupun lingkungannya (KMA No. 165 Tahun 2014 tentang Kurikulum Madrasah 2013 Mata Pelajaran PAI dan Bahasa Arab). Ruang lingkup Fikih di Madrasah Aliyah salah satunya yaitu hukum Islam tentang wakalah dan sulhu. Wakalah adalah perjanjian dimana seseorang mendelegasikan atau menyerahkan suatu wewenang (kekuasaan) pada seseorang yang lain untuk menyelenggarakan suaru urusan, dan orang lain tersebut menerimanya, dan melaksanakan untuk atas nama pemberi kuasa (Abdul Ghafur Anshari, 2010).

Adapun pengertian sulhu yaitu memutuskan pertengkaran (Hendi Suhendi, 2011). Atau sulhu dapat juga diartikan sebagai suatu akad yang bertujuan untuk mengakhiri perselisihan atau persengketaan. Dalam KMA No. 165 tahun 2014 tentang kurikulum 2013 mata pelajaran Pendidikan Agama Islam dan Bahasa Arab pada Madrasah, materi wakalah dan sulhu adalah mata pelajaran Fikih yang diajarkan di kelas X. dalam kompetensi dasar, rasa tanggung jawab termasuk ke dalam aspek afektif. Tanggung jawab dan cinta damai merupakan implementasi dari pemahaman tentang wakalah dan sulhu. Tanggung jawab adalah sikap dan perilaku seseorang untuk melakukan tugas dan kewajibannya, yang seharusnya dia lakukan terhadap dirinya sendiri, masyarakat, lingkungan (alam, sosial dan budaya), negara dan Tuhan Yang Maha Esa (Anas Salahudin dan Irwanto Alkrienciehie, 2013). Orang yang lari dari tanggung jawab berarti tidak memiliki tanggung jawab begitu juga dengan orang yang suka bermain-main adalah orang yang tidak bertanggung jawab, jadi unsur tanggung jawab itu adalah keseriusan. Cinta damai adalah sikap, perkataan dan tindakan yang menyebabkan orang lain merasa senang dan aman atas kehadiran dirinya (Ulil Amri Syafri, 2012). Dilihat dari tujuan pembelajaran Fikih tentang wakalah dan sulhu, siswa diharapkan mampu untuk memahami ketentuan Islam tentang wakalah dan sulhu karena wakalah dan sulhu sering dilakukan dalam kegiatan sehari-hari. Sehingga ketika siswa telah memahami akan hal tersebut siswa dapat mempertanggung jawabkan atas segala hal yang ia lakukan dan juga ia akan memiliki sikap cinta damai dalam kehidupannya. 
Berdasarkan studi pendahuluan yang dilakukan di Madrasah Aliyah Hasanah Pekanbaru, penulis menemukan bahwa guru telah memberikan materi Wakalah dan Sulhu dengan baik dalam pelajaran Fikih, materi ini sudah memberikan penguasaan kepada siswa tentang wakalah dan sulhu, seperti: 1) siswa dapat menjelaskan pengertian wakalah dan sulhu; 2) siswa dapat menyebutkan dasar hukum wakalah dan sulhu; 3) siswa dapat menyebutkan rukun dan syarat wakalah dan sulhu; 4) siswa dapat menyebutkan hikmah wakalah dan sulhu; 5) siswa dapat menyebutkan contoh rasa tanggung jawab dan cinta damai; 6) siswa dapat menyimpulkan pembelajaran dengan benar sesuai dengan penjelasan dari guru; 7) siswa dapat mengemukakan pendapat tentang materi wakalah dan sulhu; 8) siswa mendapat nilai yang bagus ketika ulangan harian. Namun meskipun demikian, pada kenyataannya dalam keseharian masih ditemui siswa yang belum menerapkan materi pembelajaran dalam kehidupan sehari-hari. Hal ini dapat dilihat dari gejala-gejala sebagai berikut: 1) masih ada siswa yang tidak mengerjakan tugas yang diberikan kepadanya; 2) masih ada siswa yang melimpahkan tugasnya kepada orang lain; 3) masih ada siswa yang berkelahi hanya karena persoalan kecil; 4) masih ada siswa yang suka menggunakan kata-kata sindiran yang bisa membuat temannya marah; 5) masih ada siswa yang tidak mau berusaha mendamaikan temannya yang ada konflik; dan 6) masih ada siswa yang sulit didamaikan ketika ada konflik.

Berdasarkan gejala-gejala yang ditemui di Madrasah Aliyah Hasanah Pekanbaru, penulis tertarik untuk mengetahui pengaruh pemahaman materi wakalah dan sulhu terhadap tanggung jawab dan cinta damai siswa selama di lingkungan Madasah Aliyah Hasanah Pekanbaru.

\section{METODE}

Jenis penelitian ini adalah penelitian Quasi eksperimen, dimana variable penelitian tidak mungkin dikontrol secara penuh. Kelas- kelas yang ada, dipakai untuk melakukan penelitian sehingga tidak dibuat kelas baru. Penelitian ini dilaksanakan pada bulan Mei sampai Agustus 2019, di Madarsah Aliyah Hasanah Pekanbaru. Populasi pada penelitian ini adalah siswa kelas X Madrasah Aliyah Hasanah Pekanbaru yang berjumlah 24 orang siswa. Karena jumlah populasi yang ada kurang dari 100, maka pengambilan sampel dalam penelitian ini menggunakan teknik sampel jenuh. Sampel jenuh (sensus sampling) adalah teknik penentuan sampel bila semua anggota populasi digunakan sebagai sampel.9 Teknik yang digunakan untuk memperoleh data yang diperlukan dalam penelitian antara lain: tes, angket, observasi dan dokumentasi. Dalam penelitian ini Penulis menggunakan teknik korelasi serial, yang merupakan salah satu teknik analisis data statistik yang digunakan untuk mengetahui ada tidaknya pengaruh dua variabel yang dikorelasikan. Teknik korelasi serial digunakan apabila yang dikorelasikan berskala ordinal dan interval.

\section{HASIL}

\section{Penyajian Data tentang Pemahaman Materi Wakalah dan Sulhu (Variabel X)}

Test yang digunakan oleh penulis untuk mengukur pemahaman materi wakalah dan sulhu dalam materi Fikih berupa test yang terdiri dari 15 item soal pilihan ganda (a, b, c, d dan e) dan disebarkan kepada 24 responden. Berdasarkan perhitungan di atas, diketahui bahwa nilai rata-rata siswa 84,96 berada pada rentang 80-100. Dengan demikian dapat disimpulkan bahwa pemahaman materi wakalah dan sulhu siswa berada pada kategori Sangat Baik.

\section{Penyajian Data Tanggung Jawab dan Cinta Damai Siswa (Variabel Y)}

Untuk mengukur tanggung jawab dan cinta damai siswa digunakan instrumen penelitian berupa angket yang terdiri dari 15 item pernyataan dengan alternatif jawaban selalu (SL), sering (SR), kadang-kadang (KD), jarang (JR), tidak pernah (TP). Berikut akan disajikan rekapitulasi hasil penyebaran angket tanggungjawab dan cinta damai di kalangan siswa MA Hasanah Pekanbaru.

Tabel 1. Rekapitulasi Hasil Angket Tanggung Jawab dan Cinta Damai Siswa di Madrasah Aliyah Hasanah Pekanbaru

\begin{tabular}{|c|c|c|c|c|c|c|c|c|c|c|c|c|}
\hline \multirow{3}{*}{ No Item } & \multicolumn{10}{|c|}{ Alternatif Jawaban } & \multirow{2}{*}{\multicolumn{2}{|c|}{ Jumlah }} \\
\hline & \multicolumn{2}{|c|}{$\mathrm{SL}$} & \multicolumn{2}{|c|}{ SR } & \multicolumn{2}{|c|}{ KD } & \multicolumn{2}{|c|}{ JR } & \multicolumn{2}{|c|}{ TP } & & \\
\hline & $\mathrm{F}$ & $\%$ & $\mathrm{~F}$ & $\%$ & $F$ & $\%$ & $\mathrm{~F}$ & $\%$ & $\mathrm{~F}$ & $\%$ & $\mathrm{~F}$ & $\%$ \\
\hline 1 & 17 & 70,83 & 5 & 20,83 & 2 & 8,33 & 0 & 0 & 0 & 0 & 24 & 100 \\
\hline 2 & 11 & 45,83 & 7 & 29,17 & 5 & 20,83 & 1 & 4,17 & 0 & 0 & 24 & 100 \\
\hline 3 & 9 & 37,50 & 9 & 37,50 & 6 & 25,00 & 0 & 0 & 0 & 0 & 24 & 100 \\
\hline 4 & 8 & 33,33 & 8 & 33,33 & 0 & 0 & 0 & 0 & 0 & 0 & 24 & 100 \\
\hline 5 & 8 & 33,33 & 12 & 50,00 & 4 & 16,67 & 0 & 0 & 0 & 0 & 24 & 100 \\
\hline 6 & 7 & 29,17 & 13 & 54,17 & 4 & 16,67 & 0 & 0 & 0 & 0 & 24 & 100 \\
\hline 7 & 3 & 12,50 & 8 & 33,33 & 6 & 25,0 & 0 & 0 & 0 & 0 & 24 & 100 \\
\hline 8 & 7 & 29,17 & 12 & 50,00 & 5 & 20,83 & 0 & 0 & 0 & 0 & 24 & 100 \\
\hline 9 & 8 & 33,33 & 8 & 33,33 & 6 & 25,00 & 2 & 8,33 & 0 & 0 & 24 & 100 \\
\hline 10 & 12 & 50,00 & 7 & 29,17 & 4 & 16,67 & 1 & 4,17 & 0 & 0 & 24 & 100 \\
\hline 11 & 11 & 45,83 & 9 & 37,50 & 2 & 8,33 & 2 & 8,33 & 0 & 0 & 24 & 100 \\
\hline 12 & 15 & 62,50 & 4 & 16,67 & 5 & 2,83 & 0 & 0 & 0 & 0 & 24 & 100 \\
\hline 13 & 15 & 62,50 & 8 & 33,33 & 1 & 4,17 & 0 & 0 & 0 & 0 & 24 & 100 \\
\hline 14 & 12 & 50,00 & 8 & 33,33 & 4 & 16,67 & 0 & 0 & 0 & 0 & 24 & 100 \\
\hline 15 & 8 & 33,33 & 14 & 58,33 & 2 & 8,33 & 0 & 0 & 0 & 0 & 24 & 100 \\
\hline
\end{tabular}




\begin{tabular}{|l|l|l|l|l|l|l|l|l|l|l|l|l|}
\hline Jumlah & 151 & & 132 & & 71 & & 0 & & 0 & & 360 & 100 \\
\hline
\end{tabular}

Berdasarkan tabel rekapitulasi angket tentang sikap tanggung jawab siswa diketahui bahwa alternatif jawaban: 1) Selalu terpilih sebanyak 151 kali; 2) Sering terpilih sebanyak 132 kali; 3) Kadang-kadang terpilih sebanyak 71 kali; 4) Jarang terpilih sebanyak 6 kali; dan Tidak pernah terpilih tidak ada satu pun yang memilih. Jumlah pilihan seluruhnya adalah 360 . Selanjutnya jumlah pilihan setiap alternatif jawaban dikalikan dengan skor nilai atau bobotnya masing-masing jawaban. Berdasarkan kategori di atas, diketahui bahwa angka atau skor 83,78\% berada pada rentang $81-100 \%$. Oleh karena itu, disimpulkan bahwa sikap tanggung jawab siswa di Madrasah Aliyah Hasanah berada pada kategori Sangat Baik.

\section{Uji Hipotesis}

Pengujian hipotesis penelitian dilakukan dengan teknik analisis uji analisis korelasi serial. Berdasarkan hasil analisis diperoleh informasi bahwa jumlah koreksinya adalah 1,053. Agar koefisien rch ekuivalen dengan "r" product moment, maka rch dikalikan dengan faktor koreksinya. Jadi $0,732 \times 1,053=0,771$. Selanjutnya berkonsultasi dengan tabel harga kritik product moment dengan berpatokan kepada $\mathrm{df}$ (dergee of freedom) derajat kebebasan. Dengan rumus $\mathrm{df}=\mathrm{N}-2$ jadi $24-2=$ 22. Dengan demikian rch 0,771 lebih besar dari rtabel pada taraf signifikan $5 \%$ dan $1 \%$ hal ini dapat dilihat sebagai berikut: $0,404<0,771>0,515$ atau $\mathrm{r}_{\text {hitung }}$ lebih besar dari $\mathrm{r}_{\text {tabel }}$, maka Ha yang berbunyi” ada pengaruh yang signifikan pemahaman materi wakalah dan sulhu terhadap tanggung jawab dan cinta damai siswa di Madrasah Aliyah Hasanah Pekanbaru" diterima. Dan dengan demikian HO yang berbunyi "tidak ada pengaruh yang signifikan pemahaman materi wakalah dan sulhu terhadap tanggung jawab dan cinta damai siswa di Madrasah Aliyah Hasanah Pekanbaru” dengan sendirinya ditolak. Sehingga dapat disimpulkan bahwa ada pengaruh yang signifikan pemahaman materi wakalah dan sulhu terhadap tanggung jawab dan cinta damai siswa di Madrasah Aliyah Hasanah Pekanbaru.

\section{PEMBAHASAN}

Hasil penelitian menunjukkan bahwa terdapat pengaruh pemahaman materi wakalah dan sulhu terhadap tanggung jawab dan cinta damai pada siswa. Hasil ini diperkuat oleh penelitian terdahulu yang menyatakan bahwa terdapat pengaruh yang signifikan antara pemahaman materi karakteristik wirausaha terhadap karakter tanggung jawab siswa pada pembelajaran kewirausahaan di SMK Multi Mekanik Masmur Pekanbaru. Presentase sumbangan pengaruh pemahaman materi karakteristik wirausaha terhadap karakter tanggung jawab siswa pada pembelajaran kewirausahaan di SMK Multi Mekanik Masmur Pekanbaru sebesar 34.4\%, sedangkan selebihnya dipengaruhi oleh variabel lain (Yossy Nurfadilla, 2017). Selain itu, penelitian yang dilakukan oleh penelitian lain juga mengatakan bahwa ada pengaruh yang signifikan pemahaman hukum hudud dalam materi Fikih terhadap pengendalian diri siswa Madrasah Aliyah Negeri 4 Kampar (Hilda Restinawati, (2018). Selain kedua penelitian yang relevan di atas, hasil penelitian lain juga mengatakan bahwa: 1) karakter cinta damai siswa kelas 5.2 MI Imami Kepanjen ditunjukkan dengan sikap saling mengasihi antar teman, mencegah diri dari perkelahian, tidak membeda-bedakan teman, dan tidak berbuat kasar kepada sesama teman; 2) karakter cinta damai tersebut dihasilkan dari pola asuh orang tua demokratis yang ditunjukkan dengan sikap orang tua yang selalu memberi pengarahan kepada anak untuk selalu bersikap yang baik dan saling mengasihi antar teman dan orang tua melarang anak untuk membalas perbuatan teman yang jahil, dan 3) faktor pendukung pola asuh orang tua adalah tingkat pendidikan orang tua dan kepercayaan orang tua atas pesan moral kepada anak untuk selalu berbuat baik terhadap orang lain. Sedangkan faktor penghambat pola asuh orang tua adalah sulit dalam mempengaruhi pola pikir positif kepada anak untuk selalu berperilaku baik kepada orang lain (Nurul Laily Rokhmatul Izzah, 2018).

Mempelajari Fikih bukan hanya teori yang mengutamakan ilmu pengetahuan saja. Akan tetapi ia mengandung unsur teori dan praktek. Seperti halnya dalam materi wakalah dan sulhu, setelah siswa mampu memahami teori tentang wakalah dan sulhu, diharapkan dalam aspek afektif (sikapnya), siswa juga merefleksikanna kedalam kesehariannya. Menurut Anas Sudijono (2011), "aplikasi atau penerapan mencakup pemahaman dan pengetahuan". Jadi dapat dipahami bahwa siapa yang bagus penguasaannya terhadap materi maka siswa tersebut akan mengaplikasikannya dalam kehidupan sehari-hari. Dengan demikian, jika seseorang sudah paham akan suatu ilmu maka akan mudah dalam mempraktekkannya. Pemahaman seseorang didapat dari ilmu yang dipelajarinya. Dan ilmu tersebut merupakan dasar dari segala tindakan seseorang. Jika seseorang berilmu maka ia harus diiringi dengan amal perbuatan. Sama halnya jika siswa yang telah diberikan ilmu maka perbuatannya pun akan sesuai dengan ilmu yang ia dapati. Setelah mengamalkan apa yang telah dipelajari tersebut maka akan muncul perubahan sikap pada diri seseorang. Dengan demikian setelah seseorang mempelajari dan memahami materi wakalah dan sulhu ini, maka ia akan mempraktekkannya dalam kehidupannya, dan akhirnya akan muncul sikap atau refleksi nilai setelah mengamalkan materi tersebut dalam kehidupan sehari-hari. Secara substansial mata pelajaran Fikih memiliki konstribusi dalam memberikan motivasi kepada peserta didik untuk mempraktikkan dan menerapkan hukum Islam dalam kehidupan sehari-hari sebagai perwujudan keserasian, keselarasan dan keseimbangan hubungan manusia dengan Allah swt., dengan diri manusia itu sendiri, sesama manusia, makhluk lainnya ataupun lingkungannya (KMA No. 165 Tahun 2014 tentang Kurikulum Madrasah 2013 Mata Pelajaran PAI dan Bahasa Ara).

Dalam KMA No. 165 tahun 2014 tentang kurikulum 2013 mata pelajaran PAI dan Basahasa Arab Madrasah, materi wakalah dan sulhu adalah mata pelajaran Fikih yang diajarkan di kelas X. dalam kompetensi dasar, rasa tanggung jawab termasuk ke dalam aspek afektif. Dimana rasa tanggung jawab merupakan implementasi dari pemahaman tentang wakalah dan sulhu. Sementara sulhu itu artinya adalah damai. Sulhu adalah akad yang bertujuan untuk mengakhiri perselisihan 
atau persengketaan (Hendi Suhendi, 2011). Kedamaian akan terwujud dan dirasakan baik secara pribadi atau kolektif antarmanusia, kalau masing-masing tidak menyimpan rasa benci. Kebencian akan mendorong perilaku yang tidak baik dan bermanfaat. Sementara itu kedamaian akan menghentikan sifat dan sikap destruktif dan deskriminatif. Orang yang menghidupkan nilai kedamaian akan terus berusaha menjadi orang yang memperbaiki diri dan orang-orang disekitarnya (). Oleh karena pembahasan sulhu ini adalah tetang menjaga perdamaian dan keutuhan hubungan diantara manusia, maka penulis menjadikan sikap cinta damai sebagai afektif dari pemahaman materi ini. Dan cinta damai ini termasuk dalam nilainilai yang dikembangkan dalam pendidikan budaya dan karakter bangsa (Amri Darwis, 2005). Jadi, karena materi wakalah dan sulhu ini terdiri dari dua materi, maka penulis menyesuaikan aspek afektif yang sesuai dengan materi ini. Materi wakalah dan sulhu mengandung nilai sikap tersendiri di dalam pembahasannya. Materi wakalah mengarah pada nilai tanggung jawab sedangkan sulhu mengarah pada cinta damai. Dan kedua sikap ini merupakan bagian nilai-nilai yang dikembangkan dalam pendidikan budaya dan karakter bangsa. Sehingga setelah memahamami materi ini, maka seseorang tersebut akan memiliki sikap yang terkandung dalam materi tersebut yaitu tanggung jawab dan cinta damai.

Dari penjelasan di atas, dapat ditegaskan bahwa sikap tanggung jawab dan cinta damai sedikit banyak dipengaruhi oleh pemahaman materi Fikih yaitu wakalah dan sulhu. Orang yang sudah paham akan ilmunya maka akan mudah dalam mempraktekkannya. Pemahaman seseorang didapat melalui ilmu yang dipelajarinya dan ilmu tersebut merupakan dasar dari segala tindakan seseorang jika seseorang berilmu maka ia harus diiringi dengan amal. Sama halnya jika siswa yang telah diberikan ilmu maka perbuatan pun akan sesuai dengan ilmu yang ia dapat (Bukhari Umar, 2015).

\section{SIMPULAN DAN SARAN}

\section{Simpulan}

Hasil belajar siswa yang diajar dengan pembelajaran PBL sebesar 67, 03 lebih baik dibandingkan dengan hasil belajar siswa dengan pola konvensional yakni sebesar 63,99. Aktifitas belajar siswa yang diajar dengan pembelajaran PBL sebesar 67, 58 lebih baik dibandingkan dengan aktifitas belajar siswa dengan pola konvensional yakni sebesar 57,41. Model PBL memberikan hasil lebih baik dibandingkan Model Konvensional terhadap hasil belajar siswa. Terdapat perbedaan aktifitas belajar antara siswa yang diajarkan dengan pembelajaran model PBL dengan Model belajar Konvensional. Model PBL memberikan hasil lebih baik dibandingkan Model Konvensional terhadap aktifitas belajar siswa.

\section{Saran}

Pembelajaran kooperatif model PBL dapat digunakan pada kd materi yang lain. Pembelajaran kooperatif model PBL dapat dikombinasikan dengan model pembelajaran lain agar hasil yang didapatkan lebih maksimal.

\section{DAFTAR RUJUKAN}

Abdul Ghafur Anshari, 2010, Hukum Perjanjian Islam di Indonesia, Yogyakarta: Gajah Mada University Press.

Amir, Taufiq. 2010. Pendidikan Melalui Problem Based Learning. Jakarta: Kencana Prenada Media group.

Amri Darwis, 2015, Metode Penelitian Pendidikan Islam, Pekanbaru: Suska Perss.

Anas Salahudin dan Irwanto Alkrienciehie, 2013, Pendidikan Karakter Berbasis Agama \& Budaya Bangsa, Bandung: Pustaka Setia.

Anas Sudijono, 2011, Pengantar Statistik Pendidikan, Jakarta: Raja Grafind Pesada.

Barnawi dan M. Arifin, 2016, Strategi dan Kebijakan Pembelajaran Pendidikan Karakter, Yogyakarta: Ar-Ruzz Media.

Bukhari Umar, 2015, Hadits Tarbawi: Pendidikan dalam Perspektif Hadits, Jakarta: Amzah.

Hendi Suhendi, 2011, Fiqih Muamalah, Jakarta: Rajawali Pers.

Hilda Restinawati, (2018) Pengaruh Pemahaman Hukum Hudud Dalam Materi Fikih terhadap Pengendalian Diri Siswa Kelas XI di Madrasah Aliyah Negeri 4 Kampar. Skripsi thesis, Universitas Islam Negeri Sultan Syarif Kasim Riau.

Izzah, Nurul Laily Rokhmatul (2018) Pola asuh orang tua dalam menumbuhkan karakter cinta damai pada Siswa di MI Imami Kepanjen. Undergraduate thesis, Universitas Islam Negeri Maulana Malik Ibrahim.

KMA No. 165 Tahun 2014 tentang Kurikulum Madrasah 2013 Mata Pelajaran PAI dan Bahasa Arab.

Marzuki. 2015, Pendidikan Karakter Islam, Jakarta: Amzah.

Ulil Amri Syafri, 2012, Pendidikan Karakter Berbasis Al-Qur'an, Jakarta: Rajawali Pers.

Yossy Nurfadilla, (2017) Pengaruh Pemahaman Materi Karakteristik Wirausaha terhadap Karakter Tanggung Jawab Siswa Pada Pembelajaran Kewirausahaan di Sekolah Menengah Kejuruan Multi Mekanik Masmur Pekanbaru. Skripsi thesis, Universitas Islam Negeri Sultan Syarif Kasim Riau. 